\title{
Variable utilization of shelf break-associated habitats by chick-brooding rhinoceros auklets in the California Current System
}

\author{
Bradley P. Wilkinson ${ }^{1,3, *}$, Jaime Jahncke ${ }^{2}$, Pete Warzybok ${ }^{2}$, Russell W. Bradley ${ }^{2}$, \\ Scott A. Shaffer ${ }^{1}$ \\ ${ }^{1}$ Department of Biological Sciences, San José State University, San Jose, California 95192, USA \\ ${ }^{2}$ Point Blue Conservation Science, Petaluma, California 94954, USA \\ ${ }^{3}$ Present address: Department of Forestry and Environmental Conservation, \\ and South Carolina Cooperative Fish and Wildlife Research Unit, Clemson University, Clemson, South Carolina 29634, USA
}

\begin{abstract}
Identifying frequently complex and dynamic spatial distributions of marine predators via the modeling of at-sea observations can be inherently challenging, especially when attempting to predict habitats of specific populations. Remotely-sensed tracking devices provide a viable alternative way to gather this information. We collected fine-scale spatiotemporal movement data for a small seabird, the rhinoceros auklet Cerorhinca monocerata, in the California Current System. Chick-brooding adults nesting on Southeast Farallon Island were outfitted with GPS loggers during the 2015 and 2016 breeding seasons $(n=15)$. Along with basic movement parameters, kernel density and residence time analyses were conducted to characterize at-sea distribution and identify areas of intensive use. Binomial generalized linear mixed modeling (GLMM) was used to assess foraging habitat. We found a greater utilization of areas beyond the shelf break than predicted by previous distributional models based on at-sea censuses. Interannual variation was evident, with relatively more outer break foraging in 2015 and relatively more shelf and inner break exploitation in 2016, although birds likely use the same habitat intrannually for self- and chickprovisioning. Prey availability and local oceanographic conditions may have influenced foraging decisions, with rockfish Sebastes spp. abundances and sub-mesoscale sea surface temperature (SST) fronts potentially acting as mediating factors. Results of mixed modeling highlighted a composite 3-way interaction between environmental variables facilitating auklet behavioral state switching, with an additional non-linear SST term being significant. Overall, foraging effort within the regional shelf break system appears to be variable at fine spatial scales depending on concomitant oceanographic conditions and related resource dynamics.
\end{abstract}

KEY WORDS: Shelf break - Rhinoceros auklet - Cerorhinca monocerata - Spatial ecology · Foraging behavior $\cdot$ Residence time

\section{INTRODUCTION}

Assessing distributional trends and spatial use patterns is fundamental for uncovering many key aspects of population ecology and conservation. Spatial analytics can inform predictors of habitat selection (Shaffer et al. 2009, Louzao et al. 2011, Shaver et al.

${ }^{*}$ Corresponding author: bpwilki@g.clemson.edu
2017), foraging strategies (Weimerskirch et al. 1997, Phalan et al. 2007, Rodríguez et al. 2017), and areas of significant biological importance across trophic guilds (Bost et al. 2009, Block et al. 2011). This is particularly useful in complex environments with heterogeneously available resources. The marine environment is typically described as being dynamic,

() The authors 2018. Open Access under Creative Commons by Attribution Licence. Use, distribution and reproduction are unrestricted. Authors and original publication must be credited. 
unpredictable, and hierarchically structured; therefore, characterizing the underlying spatial movements of marine predators is essential for our understanding of biologically important oceanic processes (Wakefield et al. 2009, Weimerskirch 2007). Spatiotemporal information for higher trophic predatory species can be especially useful for identifying specific mesoscale features which may be of elevated importance in a given system and which may be otherwise difficult to isolate ( $\mathrm{Nel}$ et al. 2001, Waugh et al. 2002).

With the advent of biologging devices capable of providing high resolution spatiotemporal information, remote tracking techniques have emerged as a primary tool to address these questions (Burger \& Shaffer 2008, Hays et al. 2016). While technology has previously limited the scope of these studies to species of suitable sizes for practical and ethical deployments of relatively large devices, the rapid scaling down of commercially available units has opened up avenues for researching smaller species (Rodríguez et al. 2012, Hallworth \& Marra 2015, Maxwell et al. 2016). Incorporating distributional information across a wide range of predator guilds will help build knowledge of drivers of movement at the ecosystem level and aid in identifying broad-scale management solutions (Block et al. 2016).

In addition to addressing the ecological drivers of animal movement and preferred habitat of selected species, tracking information can be used to implement, manage, and evaluate spatially-explicit conservation areas (Anderson et al. 2003, Redfern et al. 2006, Raymond et al. 2015, Young et al. 2015). Protected waters surrounding important land-based habitat, such as breeding colonies, must be adequately sized to accommodate the movements of potentially wide-ranging animals in order to maximize efficacy (Thaxter et al. 2012). Geographically static marine protected areas may provide inadequate coverage when dynamic ocean processes are taken into account; therefore spatial use assessments can provide information on adequacy and efficiency of bounded conservation areas (Studwell et al. 2017).

Here we characterize the fine scale movement patterns of rhinoceros auklets Cerorhinca monocerata (hereafter referred to as 'auklets'), a small diving seabird within the California Current System (CCS). The CCS is a highly productive eastern boundary current possessing seasonal upwelling that facilitates elevated fecundity of predator species under favorable conditions (Thayer \& Sydeman 2007). Although auklets are widely distributed along the western coast of North America, populations in the central CCS re- present the southern extent of their breeding range (Ainley et al. 1994). The results of at-sea observations of habitat use and connections to oceanographic variables for rhinoceros auklets in this region remain equivocal. For example, McGowan et al. (2013) identified the shelf break (200 m isobath) as the most prominent mesoscale feature that predicted auklet presence during summer months, a critical reproductive period when adults are spatially limited by a central place. In contrast, modeling efforts that related predator distributions to micronekton abundances across the same study region suggest that auklets are principally oceanic and outer shelf foragers during this time (Santora et al. 2012). Moreover, these analyses did not delineate between active foraging, breeding status, provenance of individuals, or movement estimations. These factors may be particularly relevant in the Gulf of the Farallones (offshore of San Francisco, CA), where a sizeable year-round nonbreeding population of mature adult auklets may exist due to competition for limited suitable nesting space (Ainley \& Boekelheide 1990). Thus, modeling marine habitat use of a specific population is more informed when including individuals of known breeding status and specific behavioral state (e.g. foraging, resting). Using accelerometers, Kato et al. (2003) obtained information about auklet foraging behavior, but lacked precise spatial or oceanographic correlates necessary for habitat quantification.

To characterize the movement patterns and habitat use of auklets in relation to oceanography, we deployed high-resolution GPS data loggers on chickrearing individuals nesting on Southeast Farallon Island (SEFI) during the 2015 and 2016 breeding seasons. We predicted that proximity to the shelf break would be a determinant factor influencing foraging behavior for this population due to local upwelling events. As auklets typically provision chicks nocturnally with a single bill load but forage diurnally, we expected trip durations to remain relatively constant (Bertram et al. 1991). However, trip distances were predicted to be influenced by central place constraints under optimal foraging theory (Burke \& Montevecchi 2009, Elliott et al. 2009). As the shelf break was hypothesized to be the prime feature concentrating auklet foraging effort, extraneous movement beyond these areas would be unexpected. In order to test these predictions, locations of intensive use by auklets were identified via residence time analysis and matched to various environmental variables. We also evaluated the coverage by regional marine sanctuaries of the spatial extent of auklet foraging distributions using estimates of home and core ranges, 
with the prediction that these areas are spatially adequate to encompass the majority of auklet distribution. Finally, we attempted to describe the preferred marine habitat of foraging auklets through behavioral state modeling.

\section{MATERIALS AND METHODS}

\section{Ethics statement}

All animal use protocols were reviewed and approved by the Institutional Animal Care and Use Committee at San José State University (\#1032). Procedures were carried out under Farallon Islands National Wildlife Refuge Research and Monitoring Special Use Permit \#81641-16-02 and United States Geological Survey (USGS) Bird Banding Lab Permits \#09316 \& 23411.

\section{Study site}

We tracked rhinoceros auklets breeding on SEFI $\left(37^{\circ} 42^{\prime} \mathrm{N}, 123^{\circ} 00^{\prime} \mathrm{W}\right)$, part of the Farallon Islands National Wildlife Refuge, California. SEFI is located offshore approximately $42 \mathrm{~km}$ west of San Francisco and $8 \mathrm{~km}$ east of the continental shelf break $(200 \mathrm{~m}$ isobath) (see Fig. 1). The largest seabird breeding colony in the contiguous USA, SEFI is surrounded locally by the Southeast Farallon Island State Marine Reserve (SFISMR) and the Southeast Farallon Island State Marine Conservation Area (SFISMCA). These 2 Marine Protected Areas (MPAs) prohibit commercial and recreational fishing over an area of $47.4 \mathrm{~km}^{2}$, with the exception of salmon trolling within SFISMCA. Regionally, the Greater Farallones National Marine Sanctuary (GFNMS) encompasses the Gulf of the Farallones, sharing a border with the Cordell Bank National Marine Sanctuary (CBNMS) to the northwest and with the Monterey Bay National Marine Sanctuary (MBNMS) to the south (see Fig. 2). These multi-use areas together cover $27648 \mathrm{~km}^{2}$ of habitat within central California and place restrictions on a range of uses, including non-renewable energy production and infrastructure development. It should be noted, however, that they do not establish management of recreational or commercial fishing, and are therefore differentiated from traditional MPAs.

\section{GPS tag deployments}

Adult auklets were captured for deployment in early July $2015(\mathrm{n}=7)$ and in late June to early July 2016 ( $\mathrm{n}=18$ ) (Table 1). Deployments coincided with the early chick-rearing phase of breeding (chicks were downy and generally <150 g). In 2015, all birds were captured by hand at pre-constructed nest boxes

Table 1. Individual summary statistics describing movement parameters for 15 chick-rearing adult rhinoceros auklets tracked from Southeast Farallon Island (SEFI) in the Californian Current System in 2015 and 2016. Sex was determined using molecular methods in 2016; validating morphometric methods used in 2015

\begin{tabular}{|c|c|c|c|c|c|c|c|}
\hline Year & Ind. & Sex & $\begin{array}{l}\text { Deployment } \\
\text { date }\end{array}$ & $\begin{array}{l}\text { Recovery } \\
\text { date }\end{array}$ & $\begin{array}{l}\text { No. of } \\
\text { trips }\end{array}$ & $\begin{array}{l}\text { Mean (min.-max.) total } \\
\text { distance per trip }(\mathrm{km})\end{array}$ & $\begin{array}{l}\text { Maximum distance } \\
\text { from SEFI }(\mathrm{km})\end{array}$ \\
\hline 2015 & 1 & M & 21 Jun & 26 Jun & 4 & $62.16(21.41-102.96)$ & 21.61 \\
\hline 2015 & 2 & $\mathrm{~F}$ & 21 Jun & 26 Jun & 4 & $87.60(64.91-115.50)$ & 31.91 \\
\hline 2015 & 3 & M & 21 Jun & 24 Jun & 3 & $34.63(29.84-38.76)$ & 7.48 \\
\hline 2015 & 4 & M & 21 Jun & 24 Jun & 3 & $44.86(24.41-60.65)$ & 25.27 \\
\hline 2015 & 5 & $\mathrm{~F}$ & 21 Jun & 24 Jun & 2 & $80.75(68.29-93.20)$ & 40.14 \\
\hline 2015 & 6 & M & 21 Jun & 24 Jun & 3 & $61.46(53.03-68.76)$ & 27.46 \\
\hline 2016 & 7 & M & $10 \mathrm{Jun}$ & 13 Jun & 3 & $42.49(40.33-46.46)$ & 14.51 \\
\hline 2016 & 8 & M & 12 Jun & 15 Jun & 3 & $37.83(27.87-43.31)$ & 7.86 \\
\hline 2016 & 9 & $\mathrm{~F}$ & 13 Jun & 16 Jun & 3 & $88.12(45.36-112.27)$ & 37.93 \\
\hline 2016 & 10 & $\mathrm{~F}$ & 16 Jun & 18 Jun & 2 & 98.03 (82.27-113.79) & 40.96 \\
\hline 2016 & 11 & $\mathrm{~F}$ & 15 Jun & 18 Jun & 2 & 98.85 (76.62-121.09) & 36.37 \\
\hline 2016 & 12 & M & 15 Jun & 19 Jun & 3 & $128.40(111.77-154.73)$ & 33.65 \\
\hline 2016 & 13 & M & 23 Jun & 26 Jun & 3 & $80.89(62.83-96.74)$ & 33.85 \\
\hline 2016 & 14 & M & $28 \mathrm{Jun}$ & $1 \mathrm{Jul}$ & 2 & $53.52(29.91-77.13)$ & 26.01 \\
\hline 2016 & 15 & $\mathrm{~F}$ & 28 Jun & $1 \mathrm{Jul}$ & 3 & $58.09(39.78-71.90)$ & 25.13 \\
\hline $\begin{array}{l}\text { Mean } \\
\text { (min.-max.) }\end{array}$ & - & - & - & - & 2.867 & $\begin{array}{c}69.57 \\
(21.41-154.73)\end{array}$ & $\begin{array}{c}27.34 \\
(7.48-40.96)\end{array}$ \\
\hline
\end{tabular}


placed by researchers and monitored for ongoing population studies. In 2016, 11 birds were captured at nest boxes while the remainder were captured utilizing either natural burrows or within boxes no longer monitored for long-term demographic studies. Upon capture, unbanded individuals were given an incoloy identification band (USGS Bird Banding Lab) on the right tarsus. GPS tags (i-gotU GT-120, MobileAction Technology) were attached to several large feathers on the back, 2 to $3 \mathrm{~cm}$ above the preening gland, using Tesa tape. Preceding deployment, GPS units were removed from their plastic encasing and re-sealed using heat-shrink tubing. This provided waterproofing and size reduction with a focus on decreasing unit weight and hydrodynamic profile. Waterproofed tags weighed $\sim 19 \mathrm{~g}$, approximately $3.7 \%$ of the average body mass of instrumented birds (513.7 g, range 462 to $600 \mathrm{~g}$ ). GPS loggers were programmed to sample a positional fix every $120 \mathrm{~s}$ and deployment durations ranged from 2 to $5 \mathrm{~d}$ depending on recovery success. Logger recovery efforts typically commenced after $3 \mathrm{~d}$, with nest checks occurring a maximum of 3 times per night until instrumented birds were recaptured. The logger was then removed and the bird released back to the nest. In both years, morphometric measurements of mass, bill depth, and wing cord were recorded. A small $(\sim 0.25 \mathrm{ml})$ blood sample was collected on filter paper (Whatman) from the webbing of the right foot (using a 25 gauge needle to puncture a blood vessel) for molecular sexing (Fridolfsson \& Ellegren 1999) in 2016 only. Sexing of auklets tracked in 2015 was completed using a linear discriminant analysis based on morphometric measurements (mass, bill depth, and wing cord) validated with molecularly sex-determined individuals. Total handling time for each logger deployment/ retrieval event was $<10 \mathrm{~min}$.

\section{Track analyses}

To delineate individual trips for each deployment track, a $1 \mathrm{~km}$ buffer around the colony was used as a threshold beyond which trips were identified. A speed filter of $80 \mathrm{~km} \mathrm{~h}^{-1}$ was also applied to each trip. This value allowed for track speeds up to 1.25 times greater than hypothesized auklet flight speeds derived from related species (Kato et al. 2003). Trips were also analyzed for temporal regularity. Given the relatively high degree of sampling rate $190 \%$ of points taken every $120 \pm 30 \mathrm{~s}$ ) tracks were not re-discretized. Descriptive movement parameters such as total trip distance, maximum straight-line distance from the colony, and trip duration were calculated for each completed excursion away from the colony. All analyses were conducted using custom routines in $\mathrm{R}$ version 3.3.2 ( $\mathrm{R}$ Core Team 2016). Mean values are reported with standard deviation (mean $\pm \mathrm{SD}$ ).

\section{Residence time analysis}

To determine locations most likely associated with active foraging, we applied residence time analyses as described in Barraquand \& Benhamou (2008) using functions in the $\mathrm{R}$ package adehabitatLT (Calenge 2006). Only complete foraging trips were considered. Residence time identifies areas of high use by imposing a virtual circle of user-defined radius over each consecutive positional fix in a trip and summing the time spent within that circle, both backwards and forwards. In addition, this metric allows the user to set a time value allowed outside the virtual circle before re-entry will no longer be considered. As auklets engaged in bouts of active foraging are anticipated to modify their behavior and increase search effort within a discrete spatial area, locations of elevated occupancy are expected to correspond with prey searching behavior (Fritz et al. 2003). We therefore predicted that areas of increased prey availability for foraging auklets will be represented by increased time of utilization. As auklets conduct trips of relatively short distance from the colony compared to more wide-ranging seabirds (average maximum distance per trip was $21.4 \pm 10.6 \mathrm{~km})$, a circle of radius $300 \mathrm{~m}$ was chosen. Impacts of variable radii on subsequent model selection were further explored through a post-hoc sensitivity analysis. Radii $(100,300,650,1000$, and $2000 \mathrm{~m}$ ) were selected based upon auklet-prey association scales recorded during 'typical' years as reported in Davoren (2000). The threshold of allowable time outside the circle prior to re-entry was set to $1 \mathrm{~h}$. This value was chosen to reflect a relatively high degree of bout specificity given reported mean dive bout durations of 15.4 and $31.8 \mathrm{~min}$ and $\mathrm{a}$ reported mean interbout interval of $50.3 \mathrm{~min}$ (Kato et al. 2003, Kuroki et al. 2003). Locations of likely foraging were identified as the upper $25 \%$ quartile of residence times per trip following Torres et al. (2011). In addition, only those points of elevated residence time occurring between civil dawn and civil dusk (both occurring when the solar angle is $6^{\circ}$ below horizon) were considered as probable foraging locations. This is based on prior evidence indicating that rhinoceros auklets are visually-based 
foragers requiring diurnal conditions for successful prey capture (Melvin et al. 1999, Takahashi et al. 1999). We therefore made the conservative assumption that any locations of high residence time occurring nocturnally were likely to be rafting behavior, as auklets are known to wait offshore close to the island before returning in complete darkness back to the nest. Additionally, anecdotal evidence of nocturnal foraging in this population indicates that it is a very rare phenomenon and not well understood (P. Warzybok pers. obs.).

\section{Foraging bearings}

Directional bearings from SEFI to the first bout of foraging as identified by the residence time analysis were calculated for each trip, as were the bearings from SEFI to the final bout of foraging. As auklet trip durations roughly approximate day length (17.1 \pm $3.0 \mathrm{~h}$ ) and foraging points were filtered to occur between civil dawn and civil dusk, we identified the first foraging bout of the day as a proxy for self-feeding areas and the final foraging bout of the day as a proxy for chick-feeding areas. This is because chickbrooding adults, returning to sea after spending the duration of the night on island with the chick, are likely to spend the first daily bouts of foraging replenishing their own body condition. Conversely, the final daily bouts of foraging are likely to be used for gathering resources for the chick, as single bill-loading species are unlikely to hold valuable resources for long durations due to risk of resource loss, interference with additional foraging, or prey dehydration (Davoren \& Burger 1999). Previous studies that characterized foraging behavior using accelerometers also support this hypothesis (Kato et al. 2003).

\section{Home range estimation}

Home range analyses were undertaken using the $\mathrm{R}$ package adehabitatHR (Calenge 2006) to examine the total area used by auklets while at sea. All trips were included in the estimation of home range, regardless of completeness. In addition, the $1 \mathrm{~km}$ buffer used to delineate individual trips was also applied to avoid introducing a bias towards time spent at or near the colony. A fixed kernel density estimation function (number of grid intervals $=300$, cell size $=0.05^{\circ}$, reference bandwidth $=0.019^{\circ}$ ) was used to determine 25, 50, 75, and 95\% utilization distributions (UD).

\section{Efficacy of national marine sanctuary (NMS) spatial coverage}

The spatial adequacy of regional NMSs was assessed in terms of both range matching and intensive habitat use. Home (95\% UD) and core (50\% UD) ranges were overlaid with boundaries of GFNMS, CBNMS, and MBNMS derived from shapefiles downloaded from the National Marine Sanctuaries Geographic Information System Dataset (http:// sanctuaries.noaa.gov/library/imast_gis.html, accessed 23 November 2016). Foraging use was assessed via percentage of intensive-use points occurring within each boundary. Local areas SFISMR and SFISMCA were excluded from analysis as the $1 \mathrm{~km}$ buffer imposed during data filtering significantly altered estimates of use in these areas.

\section{Environmental variables}

Remotely-sensed satellite data were obtained for pertinent oceanographic variables in order to characterize auklet foraging habitat. Environmental predictors were chosen to match those of McGowan et al. (2013), excluding long-range climactic indices. Sea surface temperature (SST) and chlorophyll a concentrations ( $\mathrm{chl} \mathrm{a}$ ) were obtained from the moderate resolution imaging spectroradiometer (MODIS) Aqua satellite utilizing the xtractomatic package in R (http://coastwatch.pfel.noaa.gov/xtracto/, accessed 8 February 2017). Datasets were agglomerated as $3 \mathrm{~d}$ composites with a gridded spatial resolution of $0.0125^{\circ}(\sim 1.47 \mathrm{~km})$. Bathymetric information was obtained via the NOAA National Centers for Environmental Information 3 arc-second Coastal Relief Model (https://www.ngdc.noaa.gov/mgg/coastal/crm. html). An additional $10 \mathrm{~m}$ contour (40 to $200 \mathrm{~m}$ ) shapefile specific to the Gulf of the Farallones was downloaded from the USGS Woods Hole Science Center for increased precision in identifying the $200 \mathrm{~m}$ isobath (https://pubs.usgs.gov/of/2004/1082/). Distances from positional fixes to both the shelf break and the breeding colony were calculated in R.

\section{Habitat model variable selection}

We used generalized linear mixed models (GLMMs) to examine habitat characteristics associated with intensive auklet use. Utilizing the results from the residence time analysis, each locational fix was categorized as either 'foraging' or 'non-forag- 
ing'. We then modeled the 'foraging' behavioral response as a function of remotely-sensed oceanographic variables. Prior to model exploration, chl a was log-transformed and bathymetry was squareroot transformed to increase normality. All potential predictor variables were then standardized. Correlation was assessed among all potential predictor variables via estimations from pairwise Spearman rank correlation coefficients $\left(\left|r_{\mathrm{s}}\right|<0.5\right)$. Highly correlated predictor variables were examined in conjunction, with those explaining less deviance removed. Additionally, a generalized linear model with binomial response and logit link function containing all remaining explanatory variables was fitted to auklet behavioral state. Variance inflation factors for the fitted model were then examined for values $\geq 10$ to minimize introduced collinearity following Studwell et al. (2017).

\section{Model generation}

A null GLMM with logit link binomial error distribution was fit to auklet behavioral state using the $\mathrm{R}$ function glmer in package lme4 (Bates et al. 2015). Two behavioral states were considered; 'foraging' and 'non-foraging', identified using the upper quartile residence time analysis. GLMMs were then constructed starting with the most highly parameterized linear combinations of predictor variables. Quadratic terms for SST and bathymetry were also included to account for the possibility of non-linear responses. Individual identity and year were both incorporated as random effects. Variables (random and fixed) were sequentially removed and evaluated via an information theoretic approach based on Akaike information criterion (AIC) values (Burnham \& Anderson 2002).

\section{Model selection and fit}

Competing models were assessed using a combination of AIC values and Akaike weights. As the highest-performing model (lowest AIC) was associated with a weighted confidence $>0.9$, a best single model approach was taken for evaluating model adequacy. Best-fit models were also assessed post-hoc for each chosen residence time radius metric (100, $300,650,1000$, and $2000 \mathrm{~m}$ ) and compared for model agreement. Model fit assessment was conducted on the single highest performing model through logistic regression, quantile-quantile and partial residual plots. Residuals from the fitted model were compared to simulated residuals and evaluated for linearity.

\section{RESULTS}

Data were successfully obtained from 6 (86\%) data loggers in 2015 and 10 (56\%) data loggers in 2016. Of these, 1 logger from 2016 recorded incomplete tracks and was therefore excluded from descriptive and residence time analyses. Tag recovery failure across both years included an inability to relocate the bird ( $24 \%$ of all deployments) and/or premature logger detachment (12\% of all deployments). Each deployment recorded an average of $2.9 \pm 0.6$ complete trips ( $\mathrm{n}=43$ trips).

\section{Foraging distribution}

Auklets were distributed broadly near the western edge of the Gulf of the Farallones, rarely making trips to more centrally located inshore waters. Activity was largely concentrated within an area ranging from the North Farallon Islands to the Gumdrop Seamount and Pioneer Canyon (Fig. 1). Auklets dispersed from and returned to a central place (SEFI) daily, with a majority of trips focusing on areas to the southwest of the colony. Significant movements to the north and east were uncommon. Distribution therefore did not reflect influence from coastal systems but remained in strictly pelagic zones throughout the tracking period.

\section{Foraging behavior}

There was a tendency for auklets to both initiate and terminate foraging trips within $1 \mathrm{~h}$ of civil dawn and civil dusk, respectively (51\% of trips). However, variation was present in both departure and arrival times, and in some cases adults delayed their return to the nest for several hours and approached land only under advanced darkness $(\mathrm{n}=12)$. Trip durations (range 12.43 to $26.87 \mathrm{~h}$ ) also reflected this trend, as $63 \%$ of trips were within $2 \mathrm{~h}$ of an averaged daylight length of $14.75 \mathrm{~h}$. As predicted, there was only a weak relationship between trip duration and total distance traveled (least squares linear regression, $\left.F_{1,41}=9.75, \mathrm{p}<0.01, \mathrm{R}^{2}=0.192\right)$. In addition, the relationship between trip duration and maximum distance from the colony was weakly significant $\left(F_{1,41}=5.79, \mathrm{p}<0.05, \mathrm{R}^{2}=0.123\right)$. Con- 


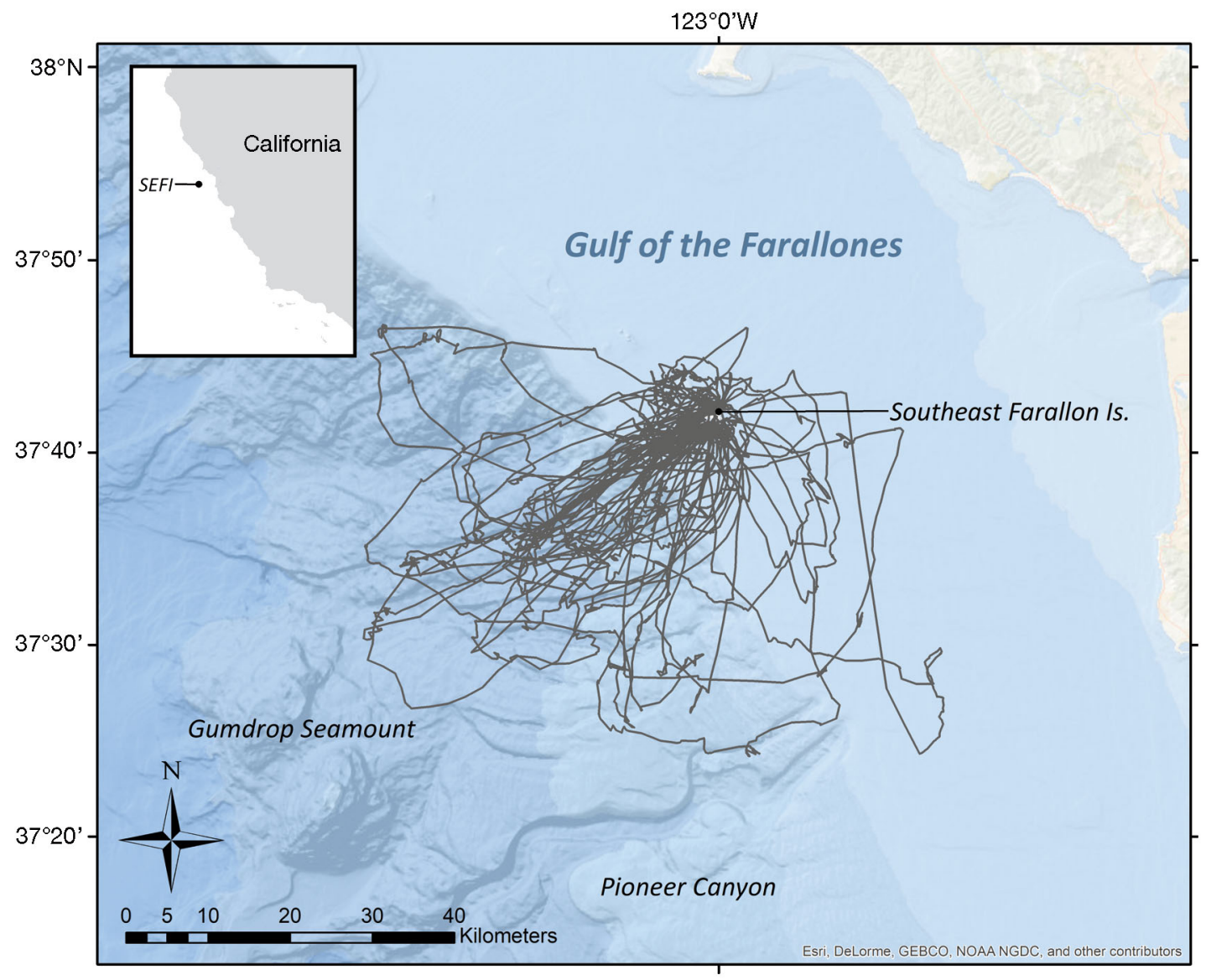

Fig. 1. Movements of chick-rearing adult rhinoceros auklets Cerorhinca monocerata breeding on Southeast Farallon Island tracked by GPS data loggers in the Californian Current System in 2015 and 2016

versely, maximum distance from the colony was a much better predictor of total distance traveled $\left(F_{1,41}=110, \mathrm{p}<0.001, \mathrm{R}^{2}=0.728\right)$. Despite the shelf break being located only $8 \mathrm{~km}$ from SFI, maximum straight line distances from the colony were routinely twice that amount (65\% of all trips) (Table 1). Indeed, mean maximum distance achieved per trip was 2.7 times further than the minimum distance required to reach the break $(21.4 \pm 10.6 \mathrm{~km})$. In addition, total trip distances $(69.6 \pm 31.9 \mathrm{~km})$ were greater than would be expected for flights simply occurring to the shelf break and returning to the colony. This was further supported by the residence time analysis, which delineated foraging points throughout the study area. This included foraging effort in waters over the continental shelf, within the break region, and in deeper semi-pelagic waters. Although the most significant cluster of foraging points was located in shallow (0 to $200 \mathrm{~m}$ ) continental waters to the southwest of SEFI, a secondary cluster of activity was located over the outer shelf corresponding to bathymetric values between 1000 and
$2000 \mathrm{~m}$. This distribution of intensive use areas was confirmed by the kernel density analysis, which produced separate core ranges ( $50 \%$ UD) centered over these respective marine sectors (Fig. 2).

There was a consistent directional bearing associated with the shelf break for both initial and final foraging bouts (Fig. 3). This bearing is consistent with the most expedient line of travel to and from the shelf break $\left(221 \pm 62^{\circ}\right)$ from SEFI, despite potential foraging efforts significantly beyond the immediate $200 \mathrm{~m}$ isobath. To test for environmental differences between the first and last foraging bout locations, oceanographic variables between initial and final intensive use points were compared using bootstrapped 2-sample Kolmogorov-Smirnov tests (1000 iterations). We found that differences in $\operatorname{SST}(D=$ $0.233, \mathrm{p}>0.05)$, log-transformed chl a $(D=0.186$, $\mathrm{p}>0.05)$, square-root transformed bathymetry $(D=$ $0.209, \mathrm{p}>0.05)$, distance to the shelf break $(D=$ $0.116, \mathrm{p}>0.05)$, and distance to the colony $(D=0.186$, $\mathrm{p}>0.05$ ) were not significant between the first and last daily foraging bouts across trips. 


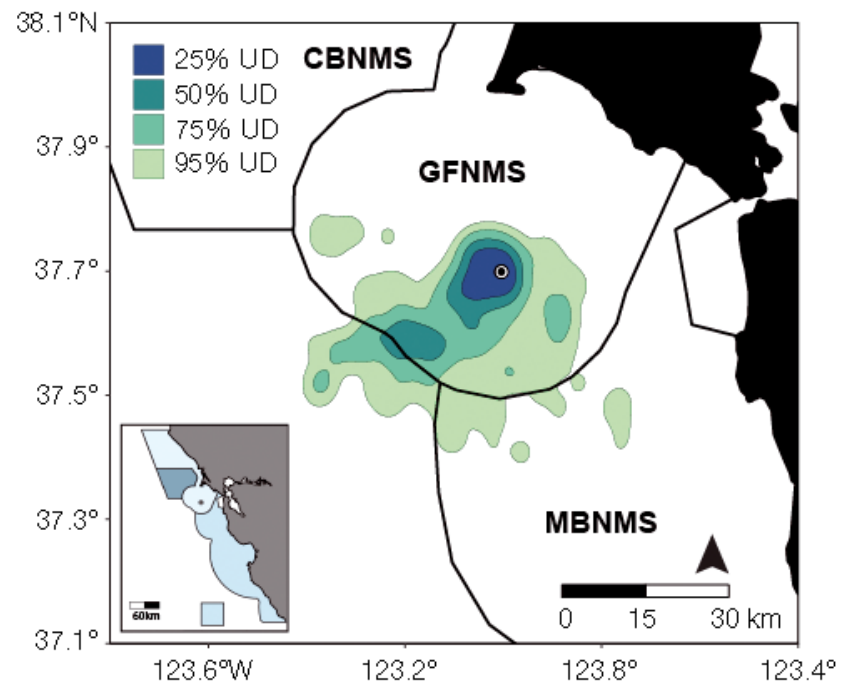

Fig. 2. Kernel density plot of all foraging trips recorded by adult rhinoceros auklets breeding on Southeast Farallon Island (white circle) in 2015 and 2016, in relation to surrounding marine sanctuaries. Core and home ranges are represented by the $50 \%$ and $95 \%$ utilization distributions (UD), respectively. The full extent of central Californian marine sanctuaries is shown in the inset map. GFNMS: Greater Farallones National Marine Sanctuary; CBNMS: Cordell Bank National Marine Sanctuary; MBNMS: Monterey Bay National Marine Sanctuary

\section{Overlap with marine sanctuaries}

Kernel density estimation of home range (95\% UD) indicated that the majority of auklet habitat was encompassed by a spatially-explicit conservation area (Fig. 2). For example, GFNMS encompassed $68 \%$ or greater of the total locations, foraging locations,

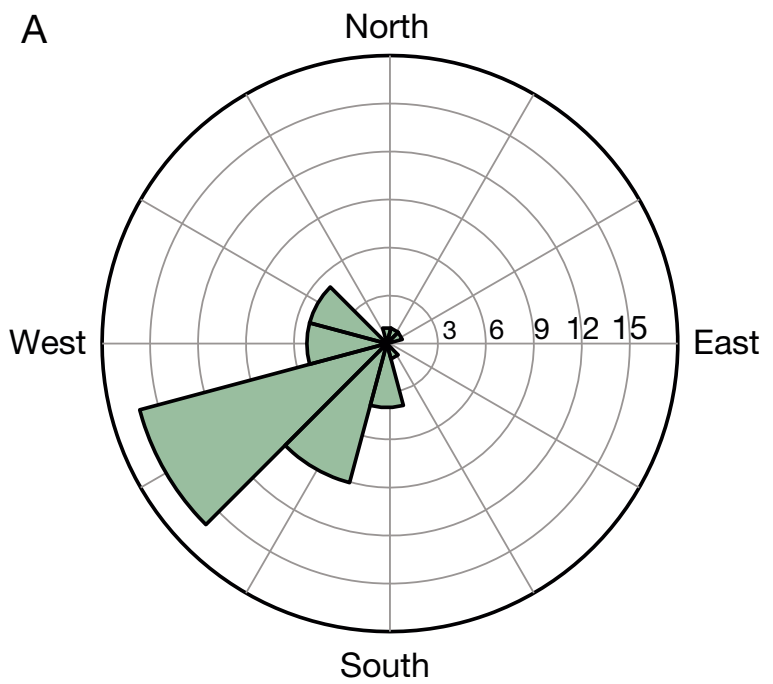

home range distribution, and core range distribution. MBNMS was only marginally used, with $<15 \%$ coverage in all categories. There was a complete absence of auklet locations within CBNMS although its border was approached on 2 separate trips. The remainder of positional fixes, particularly for foraging points and home range distribution, overlapped with waters outside of the marine sanctuaries (Table 2).

\section{Comparison of oceanography}

Habitat modelling indicated complex interactions of oceanographic variables for predicting behavioral changes in foraging auklets. During variable selection, distance to colony was removed due to high absolute value correlation coefficients with all other input predictors $(0.86,0.48,0.48$ and 0.47 for bathymetry, $\log \left[\begin{array}{ll}\mathrm{chl} & a\end{array}\right], \mathrm{SST}$ and distance to shelf, respectively). Due to limited fixed effects and $\left|r_{\mathrm{s}}\right|$ values below or near 0.5 , all remaining predictor variables were included in model generation. Sensitivity analyses revealed strong model agreement at scales of 100, 300, and $650 \mathrm{~m}$ residence time radii. Best candidate models generated at these 3 radii all contained the same 3-way interaction, although differences arose in the quadratic term ( $\mathrm{SST}^{2}$ was missing in one of 2 top candidate models at $100 \mathrm{~m}$, and replaced by bathymetry $^{2}$ in the lone top model at $650 \mathrm{~m}$ ) (Table 3). The best candidate model generated at a $1000 \mathrm{~m}$ scale included a separate 3 -way interaction and both quadratic terms as significant. Finally, residence times generated at $2000 \mathrm{~m}$ scales indicated foraging bouts

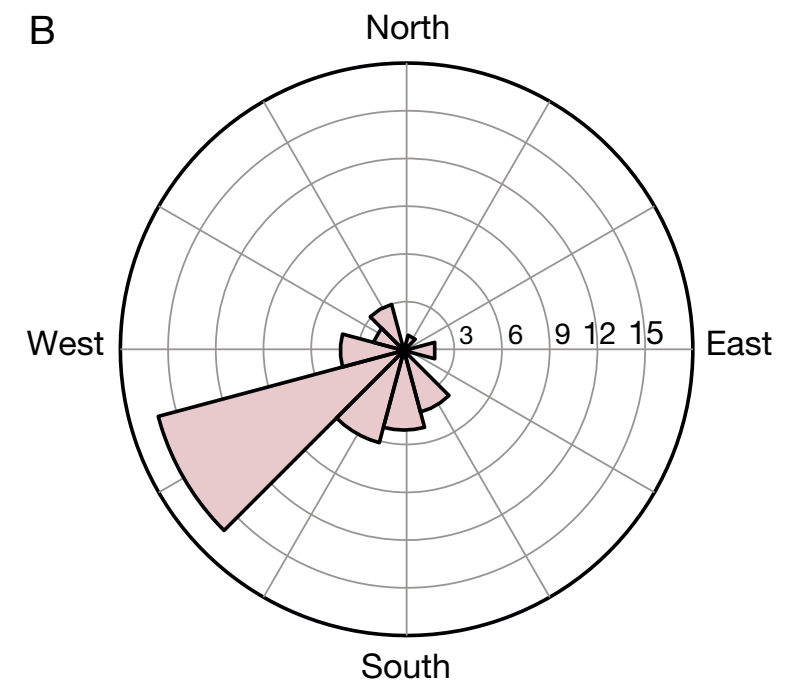

Fig. 3. (A) Bearings from Southeast Farallon Island (SEFI) to the first identified point of intensive use in each foraging trip by adult rhinoceros auklets tracked in 2015 and 2016, a proxy for probable locations of self-foraging behavior. (B) Bearings from SFI to the final point of intensive use in each trip, a proxy for probable locations of chick-foraging behavior 
Table 2. Regional marine sanctuary use by foraging adult rhinoceros auklets tracked from Southeast Farallon Island (SEFI) in the Californian Current System in 2015 and 2016. GFNMS: Greater Farallones National Marine Sanctuary; CBNMS: Cordell Bank National Marine Sanctuary; MBNMS: Monterey Bay National Marine Sanctuary. UD: utilization distribution

\begin{tabular}{|lcccccc|}
\hline $\begin{array}{l}\text { Marine } \\
\text { sanctuary }\end{array}$ & $\begin{array}{c}\text { No. of locations } \\
\text { in boundary }\end{array}$ & $\begin{array}{c}\text { \% locations } \\
\text { in boundary }\end{array}$ & $\begin{array}{c}\text { No. of foraging } \\
\text { points in } \\
\text { boundary }\end{array}$ & $\begin{array}{c}\text { \% foraging } \\
\text { points in } \\
\text { boundary }\end{array}$ & $\begin{array}{c}\text { \% home range } \\
\text { in boundary } \\
(95 \% \text { UD) }\end{array}$ & $\begin{array}{c}\% \text { core range } \\
\text { in boundary } \\
(50 \% \text { UD) }\end{array}$ \\
\hline GFNMS & 15252 & 81.56 & 2775 & 73.20 & 68.61 & 95.22 \\
MBNMS & 1144 & 6.12 & 296 & 7.81 & 0 & 0 \\
CBNMS & 0 & 0 & 0 & 18.33 & 18.06 & - \\
Unprotected & 2305 & 12.32 & 720 & - & - \\
Total & 18701 & - & 3791 & & & - \\
\hline
\end{tabular}

Table 3. Highest-performing models based on Akaike information criterion (AIC) of the behavioral state of chick-rearing rhinoceros auklets in the Gulf of the Farallones (Californian Current System). Models were generated at a range of residence time radii (100-650 m). High concordance among models indicates a significant relationship between auklet behavioral state and a 3-way interaction of distance to shelf, $\log (\mathrm{chl} \mathrm{a})$, and bathymetry. A non-linear relationship with SST also occurred in half of the top models, indicating likely importance across smaller radii

\begin{tabular}{|llll|}
\hline $\begin{array}{l}\text { Residence time } \\
\text { radius }(\mathrm{m})\end{array}$ & Model fixed effects & $\begin{array}{c}\text { Model random } \\
\text { effect }\end{array}$ & $\begin{array}{c}\text { AIC } \\
\text { weight }\end{array}$ \\
\hline 100 & Dist. to shelf $\times \log (\mathrm{chl} a) \times$ Bathymetry + SST & Individual \\
100 & Dist. to shelf $\times \log (\operatorname{chl} a) \times$ Bathymetry + SST $+\mathrm{SST}^{2}$ & Individual & 0.63 \\
300 & Dist. to shelf $\times \log (\operatorname{chl} a) \times$ Bathymetry + SST $+\mathrm{SST}^{2}$ & Individual & 0.37 \\
650 & Dist. to shelf $\times \log (\mathrm{chl} a) \times$ Bathymetry $+\mathrm{SST}+$ Bathymetry & 0.99 \\
& & Individual & 0.99 \\
\hline
\end{tabular}

of unrealistic duration and homogenization (i.e. one very long foraging bout per trip) and so were not modeled. Given the high agreement between models generated at local scales (100, 300, and $650 \mathrm{~m})$, we elected the median scale of $300 \mathrm{~m}$ as most appropriate (Table 3). The highest performing model included a three-way interaction between distance to shelf, $\log (\mathrm{chl} a)$, and bathymetry along with a quadratic
SST term and individual identity as a random effect $(\Delta \mathrm{AIC}=16.9)($ Table 3$)$. Akaike weights $(w)$ indicated this model to be significantly more likely to be the best model for explaining auklet behavioral state over other candidate models $(\mathrm{n}=25)(w=0.99)$. Logistic regression and partial residual plots indicated no major departures from model assumptions, and that appropriate model fit was achieved (Table 4).
Table 4. Summary statistics for the highest performing single model of rhinoceros auklet foraging behavior in the Gulf of the Farallones (Californian Current System) using a $300 \mathrm{~m}$ residence time radius metric. Highly significant terms $(\mathrm{p}<0.001)$ are denoted with an asterisk. Note that while not all covariates or interactions were significant, the 3-way interaction term contributed heavily to the model. All model parameters have been standardized for comparative purposes

\begin{tabular}{|c|c|c|c|c|}
\hline \multirow[t]{2}{*}{ Model parameter } & \multicolumn{2}{|c|}{ Coefficient } & \multirow[t]{2}{*}{$Z$-score } & \multirow[t]{2}{*}{$\mathrm{p}$-value } \\
\hline & Estimate & SE & & \\
\hline Intercept* & -1.506 & 0.198 & -7.621 & $<0.001$ \\
\hline Dist. to shelf & -0.040 & 0.046 & -0.870 & 0.384 \\
\hline $\log (\operatorname{chl~} a)^{*}$ & -0.310 & 0.046 & -6.778 & $<0.001$ \\
\hline Bathymetry* & -0.321 & 0.037 & -8.684 & $<0.001$ \\
\hline $\mathrm{SST}^{*}$ & 0.205 & 0.041 & 5.047 & $<0.001$ \\
\hline $\log (\operatorname{chl} a) \times$ Dist. to shelf & -0.160 & 0.087 & -1.850 & 0.064 \\
\hline Bathymetry $\times$ Dist. to shelf* & 0.144 & 0.042 & 3.398 & $<0.001$ \\
\hline $\log (\operatorname{chl} a) \times$ Bathymetry & 0.021 & 0.051 & 0.402 & 0.688 \\
\hline Log $($ chl a) $\times$ Dist. to shelf $\times$ Bathymetry $*$ & * 0.493 & 0.105 & 4.681 & $<0.001$ \\
\hline $\mathrm{SST}^{2 *}$ & 0.148 & 0.028 & 5.207 & $<0.001$ \\
\hline
\end{tabular}

\section{DISCUSSION}

Foraging rhinoceros auklets brooding chicks at Southeast Farallon Island are able to exploit multiple marine habitats ranging from the continental shelf to outer break domains. Despite variable fine-scale habitat choices, the shelf break system at large appears to be the most fundamentally important mesoscale feature in the region influencing auklet behavior. Local foraging decisions nested within this system appear to be modulated by complex interactions of oceanography (primarily among bathymetry, primary produc- 
tivity, and distance from the shelf). In addition, there exists a significant non-linear relationship with local SST. Despite a separation of core use areas between inner-shelf and outer-shelf domains, we were unable to find evidence supporting a separation of self- and chick-provisioning habitats. The majority of this habitat is distributed within NMS boundaries, with significant departures to the unprotected outer break.

Modeling marine predator distributions through at-sea observational data can be an effective method for quantifying space use across wide geographic bounds (Vilchis et al. 2006, Panigada et al. 2008, Keller et al. 2012). However, model outputs can be influenced by predictor variable selection, analytic methodology, and observer biases. In addition, information on individual origin, behavioral state, movement parameters, and spatial dynamism is often missing. These issues can lead to misclassifications of habitat when applied to specific populations. For example, observational summertime modeling efforts produced equivocal results for rhinoceros auklets in the Gulf of the Farallones despite the presence of a breeding colony on SEFI (Santora et al. 2012, McGowan et al. 2013).

Though prior models were complementary in nature, model discrepancy may have resulted from differing input variables, model design, varying data sources, or temporal mismatch. The addition of fine-scale movement data for individual auklets should therefore be included when assessing the ecological requirements of regionally based breeding populations (e.g. Yamamoto et al. 2015). Our analysis suggests an elevated dependence on outer shelf waters for chick-rearing auklets breeding in the Farallon Islands, the major colony for the species in the central CCS. Residence time analysis of individual foraging trips showed clusters of highintensity use in both near-island and shallower shelf waters, and in semi-pelagic oceanic sectors beyond the $200 \mathrm{~m}$ isobath. It seems likely that auklets benefit from exploiting upwelling-driven areas responsible for concentrating resources, and that the shelf break system at large is the primary mesoscale feature utilized by foraging adults. The prediction regarding the importance of this feature was, therefore, only partially accurate. While largely influential on a distributional scale, auklets often exploit multiple habitats within this system.

Evidence from foraging bearings (Fig. 3) together with remotely sensed oceanographic data also suggest that self-provisioning habitat and chick-provisioning habitat are not significantly different for prey-searching auklets on an intra-annual basis. As discrete foraging areas for initial and final daily bouts should have produced differing habitat profiles, the environmental similarity indicates that auklets do not discriminate between resource gathering areas for self and for offspring. This lends support to prior prey selection and stable isotope analyses which concluded that adults and chicks shared similar diets (Ito et al. 2009, Carle et al. 2015).

Interestingly, foraging adult auklets in 2015 showed a stronger specificity to the outer shelf break region (1000 to $1500 \mathrm{~m}$ ) than birds in 2016, which had more uniformly distributed foraging locations (Fig. 4). We believe this trend may have been driven in part by local SSTs during the tracking period. Remotely sensed oceanographic data indicated that there was a strong temperature gradient present along the outer break during the first year of this study, which was consistent with locations of intensive auklet use identified by the residence time analysis (Fig. 5). In contrast, oceanographic conditions the following year were more homogeneous; SSTs were warmer throughout both inner and outer break domains. In addition to a decreased dependence on the outer shelf break in 2016, track bearings of auklets appeared more dispersive. We posit that auklets tracked in 2016 searched more radially from SEFI for sub-mesoscale temperature fronts to exploit or potentially limited their foraging effort to trips within the inner shelf, which contained relatively lower SSTs than the outer break. It should be noted however that these 2 hypotheses are not mutually exclusive, and that different strategies may have been used by different individuals. We therefore suggest that both inner and outer break habitats can be exploited by foraging auklets, but that local SST is an important factor mediating this habitat selection, reflected in the non-linear relationship apparent in behavioral state modeling. More data collected across additional years are needed to fully address the mechanisms that drive these differences.

Foraging auklets also appear to respond to indices of primary productivity ( $\mathrm{chl}$ a) variably, depending upon shelf break-associated habitat. Examining interaction trends between distance from the shelf, bathymetry, and primary productivity on behavioral state revealed 2 similar groupings (Fig. 6). When in semi-pelagic offshore (deep water, far from the shelf break) and inner shelf break (shallow water, close to the shelf break) habitats, auklets showed a positive trend in switching to a foraging behavioral state with increasing primary productivity. In continental shelf (shallow water, far from the break) and outer shelf 

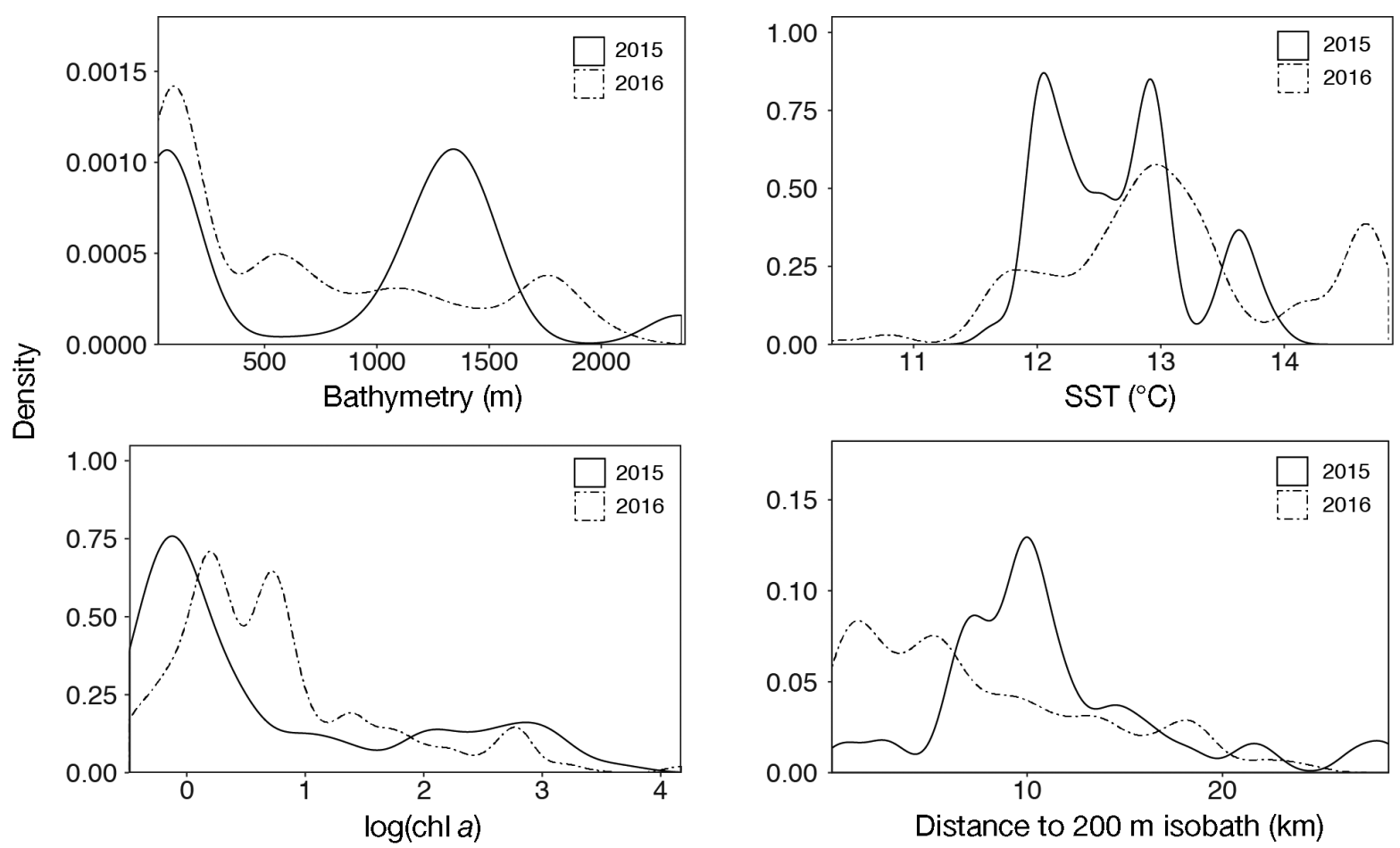

Fig. 4. Density plots of intensive use locations for adult rhinoceros auklets tracked in the Californian Current System in 2015 and 2016 in relation to modeled oceanographic variables. Notice the bimodal selection of intensive use locations in 2015 at bathymetries between 1000 and $1500 \mathrm{~m}$, in addition to shelf foraging, as well as the generally cooler SSTs in 2015 compared to 2016. This is further illustrated in the distances to shelf, with 2016 foraging locations generally being located closer to the $200 \mathrm{~m}$ isobath

break (deep water, close to the break) habitats, model results indicated a negative behavioral state switching trend in the presence of elevated primary productivity. These groupings also appear reflected in the foraging tracks. As regionally elevated chl a concentrations during both years were predominantly distributed inside the $200 \mathrm{~m}$ isobath, levels of primary productivity at inner versus outer shelf break habitats may have been highly divergent (Fig. 5). This break-associated contrast may have contributed, along with effects of SST, to the relative paucity of foraging points just beyond the shelf break in 2015. In addition, auklets appeared to select for relatively high levels of primary productivity when in semi-pelagic offshore habitats compared to the surrounding seascape during both years. While also likely influenced by sub-mesoscale SST fronts, auklets may therefore prefer to forage in local patches of elevated primary productivity away from the continental shelf.

Temporally matched dietary samples collected on SEFI in 2015 and 2016 from a random sample of provisioning adult auklets also indicated a putative switch in foraging strategies between years. Diet samples were dominated by northern anchovy En- graulis mordax and juvenile rockfish Sebastes spp. (primarily $S$. jordani), characteristic species of the regionally available marine prey assemblage (Miller \& Sydeman 2004, Elliott et al. 2015). However, the percentage of anchovy occurrence decreased between years (from $62 \%$ in 2015 to $22 \%$ in 2016) while juvenile rockfish occurrence increased (from $29 \%$ in 2015 to $63 \%$ in 2016) (Point Blue Conservation Science, unpubl. data). Although prey assemblages are similar between shelf break domains, juvenile rockfish abundances have been found to decrease in the outer mid-break region (Santora et al. 2012). This may be exacerbated by possible population trends in regional rockfish stocks shifting to more nearshoredominant species (Elliott et al. 2015). It therefore seems likely that the increased importance of anchovy in 2015 reflected the greater use in that year of the outer shelf break, where rockfish are generally less abundant. Correspondingly, the decreased significance of this sector in 2016, when there was more inner break and shelf foraging, is indicated by a greater occurrence of rockfish in the diet for that year.

Prey availability is also known to be modulated by longer-term indices (Suryan et al. 2006, Ancona et al. 

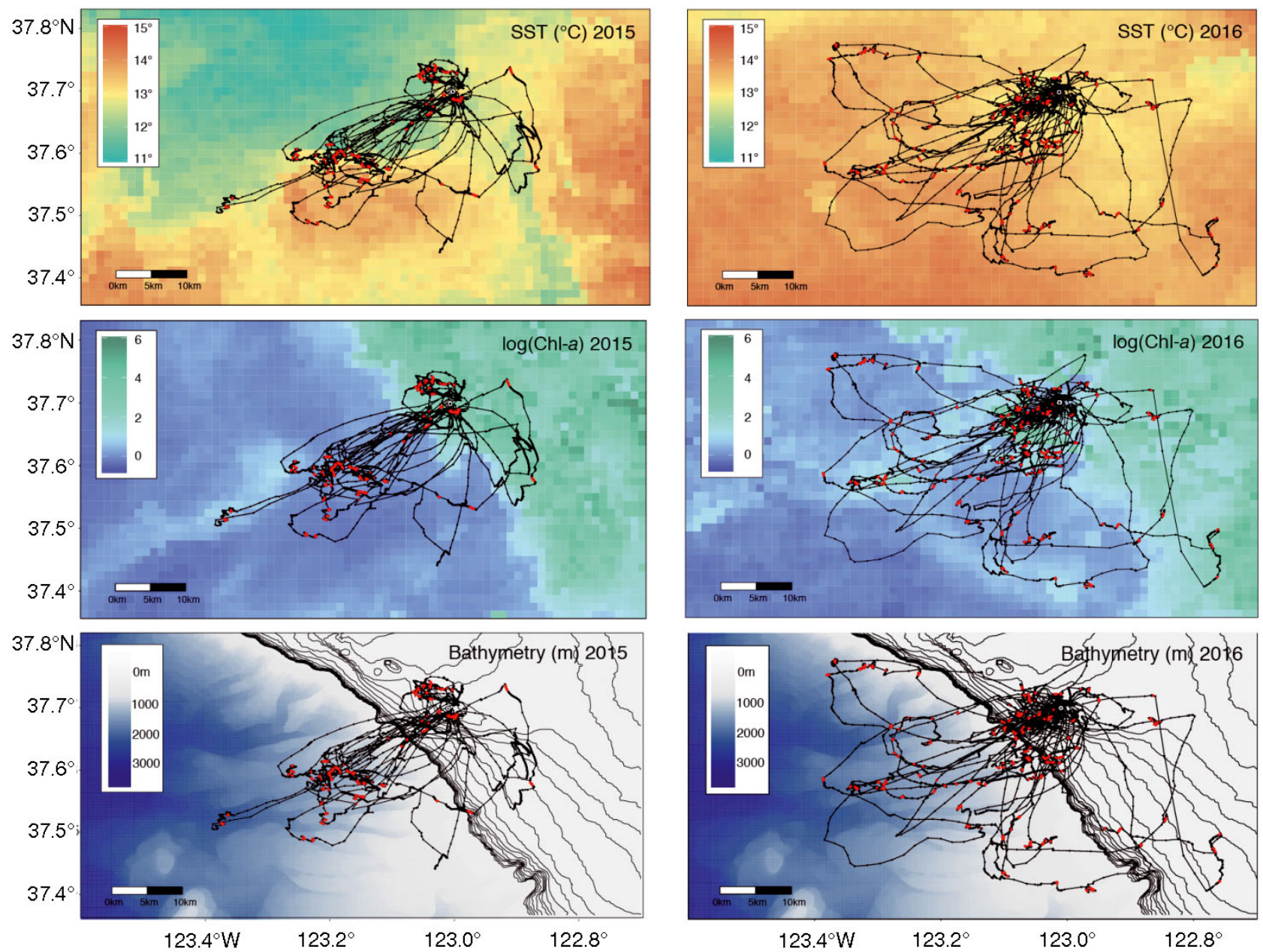

Fig. 5. Tracked locations of foraging adult rhinoceros auklets in the Californian Current System relative to remotely-sensed oceanographic variables in 2015 (left panels) and 2016 (right panels). The breeding site on Southeast Farallon Island is represented by a white marker. Locations of intensive use are identified by red dots. Maps of SST (top) and log(chl a) (middle) were generated using Aqua MODIS data agglomerated as $8 \mathrm{~d}$ composites centered on the median tracking day per year with a gridded spatial resolution of $0.0125^{\circ}(\sim 1.47 \mathrm{~km})$. In the bathymetry plots (bottom) $10 \mathrm{~m}$ contour lines to $200 \mathrm{~m}$ are shown to highlight the position of the shelf break

2012). For example, during years of strong late winter upwelling and generally lower SSTs, rockfish abundances increase near SEFI (Miller \& Sydeman 2004, Black et al. 2010). This has been determined by scientific trawls and occurrence in auklet diets, which show a strong correlation (Thayer \& Sydeman 2007). Anchovy, however, appear more behaviorally plastic and able to buffer anomalous environmental conditions (Robinson 2004). During years of weak upwelling, anchovy tend to dominate the available prey assemblage (Wells et al. 2017). Despite local SST conditions being cooler during the auklet chick-rearing period, rockfish abundances were generally depressed in 2015 following a very warm water event the previous winter, as evidenced by trawl data and diet indices (Point Blue Conservation Science, un- publ. data). Winter conditions in 2016, however, were slightly more favorable and may have allowed for increased rockfish recruitment.

Underlying prey availability, in conjunction with local spatiotemporal oceanographic conditions, may therefore have influenced auklet foraging decisions between the 2 years of our study. It should be noted, however, that these characterizations should be interpreted with caution. Our results may have arisen from spatially autocorrelated hierarchies or individual preference between years, given the small sample size and limited study duration. In addition, the underlying causal relationships between environmental conditions and prey availability remain complex and unclear (Hyrenbach \& Veit 2003, Ainley \& Hyrenbach 2010, Santora et 


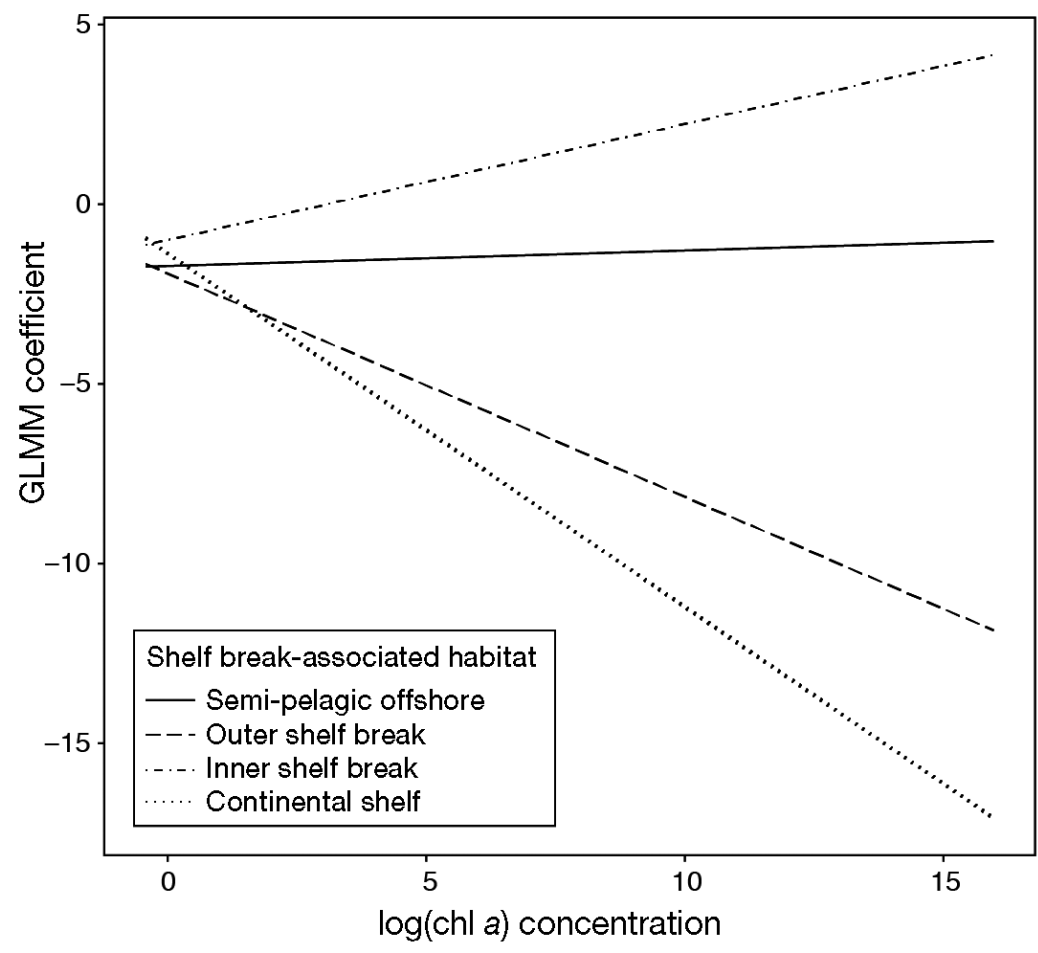

Fig. 6. Modeled influence of 3-way interaction of bathymetry, distance to shelf, and $\log (\mathrm{chl} \mathrm{a})$ on behavioral state of foraging adult rhinoceros auklets tracked in the Californian Current System in 2015 and 2016. Shelf break associated habitats were categorized as semi-pelagic offshore (deep water, far from shelf break), outer shelf break (deep water, close to shelf break), inner shelf break (shallow water, close to shelf break), and continental shelf (shallow water, far from shelf break). Probability of foraging increased with chl $a$ in semi-pelagic offshore and inner shelf break habitats, but decreased as chl $a$ increased in outer shelf break and continental shelf habitats only marginal importance for this population. The absence in habitat use by auklets in the CBNMS is most likely influenced by the position of the shelf break relative to SEFI. Given that the most direct line of travel to the break is achieved by following a southwesterly bearing, it is unlikely that preysearching auklets would venture greater distances to the northwest. As current NMS boundaries tend to favor shelf habitats over break systems, extending protections to encapsulate distal outer zones may benefit oceanic and semi-oceanic organisms throughout the region. In addition, although NMS designation confers protection against development and infrastructure, it does not confer regulatory management of commercial or recreational fisheries. Stocks of important forage fish must therefore be independently monitored to prevent depletion. While the local SFISMR and SFISMCA do prohibit most fishery activities, given their relatively small spatial area and proximity to the colony, protection of these areas likely offers negligible benefits to foraging auklets.

\section{CONCLUSION}

al. 2014). However, our results are consistent with previous ecological assessments.

Evaluation of regional conservation zones with auklet movement data indicated a relatively robust spatial overlap between adult distribution and national marine sanctuaries (Fig. 2). As expected, GFNMS provided the greatest overlap in coverage of auklet habitat use at sea (Table 2). Given that SEFI is located centrally within the borders of this NMS, the main concern was not presence of protection per se but rather the spatial efficacy of the existing protection. We determined that while auklets typically remained within sanctuary zones possessing limited protective management, significant foraging did occur outside of sanctuary waters. These departures from regional NMSs were characterized by outer-break foraging that typically occurred at maximal distances from the colony. In contrast, the overall use of MBNMS for foraging was nearly half that of the home range estimate. While MBNMS waters may be used as probable resting, transit, or exploratory areas, the potential benefit to foraging activities appears to be of
We have shown, through our use of fine-scale GPS tracking, that adult auklets rearing chicks at SEFI target the shelf and the outer break oceanic zones when foraging. Local environmental conditions likely modulate foraging strategy during this period, as well as interannual variations in resource composition, availability, or abundance. These findings, though broad, fit theoretical models of generalist predator species (Harcourt et al. 2002, Matich et al. 2011). Despite potential interannual variation, we provide further evidence supporting the conclusion that adults utilize the same habitat for self- and chick-provisioning throughout the chick-rearing period. Modeling efforts underscored the complexity of environmental cues influencing foraging behavior, with multiple oceanographic interactions likely contributing to utilization distributions. Long-term tracking studies of this species, combined with environmental data and diet composition, would greatly 
expand our understanding of these factors. Finally, marine sanctuaries at the regional scale appear adequate for containing much of the distribution of foraging auklets despite favoring shelf waters. However, auklets may demonstrate an expansion in range during incubation or late chick-rearing, common in similar species (Ito et al. 2010, Shoji et al. 2016). In addition, recent investigations into non-breeding movement patterns of auklets elsewhere in the Pacific indicate complex migratory patterns (Takahashi et al. 2015), and current boundaries should be evaluated at other stages of life history as well.

Acknowledgements. This work was funded through support by the National Geographic Society, California State University Council on Ocean Affairs, Science, and Technology, Myers Oceanographic and Marine Biology Trust, and the San José State University Department of Biological Sciences. Permission to access the field site was granted by the Farallon Islands National Wildlife Refuge. Logistical and field support was provided by Point Blue Conservation Science. L. Miller and B. Carter provided valuable comments on drafts of the manuscript, statistical guidance, and coding support. We thank the volunteers on SEFI who assisted in data collection, and the members of the ShAPE Lab for sharing helpful advice, encouragement, and knowledge. Additional funding for Point Blue's Farallon research was provided by the Bently Foundation, Baker Trust, Marisla Foundation, Mead Foundation, Campini Foundation, Bernice Barbour Foundation, Kimball Foundation, RHE Charitable Foundation, Volgenau Foundation, and individual donors. The Farallon Patrol supported our research through crew transfers and re-provisioning of the island. This is Point Blue Contribution \#2141.

\section{LITERATURE CITED}

Ainley DG, Boekelheide RJ (1990) Seabirds of the Farallon Islands. Stanford University Press, Palo Alto, CA

Ainley DG, Hyrenbach DK (2010) Top-down and bottom-up factors affecting seabird population trends in the California current system (1985-2006). Prog Oceanogr 84: 242-254

Ainley DG, Sydeman WJ, Hatch SA, Wilson UW (1994) Seabird population trends along the west coast of North America: causes and the extent of regional concordance. Stud Avian Biol 15:119-133

Ancona S, Calixto-Albarrán I, Drummond H (2012) Effect of El Niño on the diet of a specialist seabird, Sula nebouxii, in the warm eastern tropical Pacific. Mar Ecol Prog Ser 462:261-271

Anderson DJ, Huyvaert KP, Wood DR, Gillikin CL, Frost BJ, Mouritsen H (2003) At-sea distribution of waved albatrosses and the Galapagos Marine Reserve. Biol Conserv 110:367-373

Barraquand F, Benhamou S (2008) Animal movements in heterogeneous landscapes: identifying profitable places and homogeneous movement bouts. Ecology 89:3336-3348

Bates D, Machler M, Bolker B, Walker S (2015) Fitting linear mixed-effects models using lme4. J Stat Softw 67:1-48
Bertram DF, Kaiser GW, Ydenberg RC (1991) Patterns in the provisioning and growth of nestling rhinoceros auklets. Auk 108:842-852

Black BA, Schroeder ID, Sydeman WJ, Bograd SJ, Lawson PW (2010) Wintertime ocean conditions synchronize rockfish growth and seabird reproduction in the central California Current ecosystem. Can J Fish Aquat Sci 67: 1149-1158

* Block BA, Jonsen ID, Jorgensen SJ, Winship AJ and others (2011) Tracking apex marine predator movements in a dynamic ocean. Nature 475:86-90

* Block BA, Holbrook CM, Simmons SE, Holland KN and others (2016) Toward a national animal telemetry network for aquatic observations in the United States. Anim Biotelem 4:6

Bost CA, Cotté C, Bailleul F, Cherel Y and others (2009) The importance of oceanographic fronts to marine birds and mammals of the southern oceans. J Mar Syst 78:363-376

Burger AE, Shaffer SA (2008) Application of tracking and data-logging technology in research and conservation of seabirds. Auk 125:253-264

Burke CM, Montevecchi WA (2009) The foraging decisions of a central place foraging seabird in response to fluctuations in local prey conditions. J Zool 278:354-361

Burnham KP, Anderson DR (2002) Model selection and multi-model inference: a practical information-theoretic approach. Springer, New York, NY

Calenge C (2006) The package 'adehabitat' for the R software: a tool for the analysis of space and habitat use by animals. Ecol Model 197:516-519

* Carle RD, Beck JN, Calleri DM, Hester MM (2015) Temporal and sex-specific variability in rhinoceros auklet diet in the central California Current system. J Mar Syst 146: 99-108

* Davoren GK (2000) Variability in foraging in response to changing prey distributions in rhinoceros auklets. Mar Ecol Prog Ser 198:283-291

* Davoren GK, Burger AE (1999) Differences in prey selection and behaviour during self-feeding and chick provisioning in rhinoceros auklets. Anim Behav 58:853-863

${ }^{2}$ Elliott KH, Woo KJ, Gaston AJ, Benvenuti S, Dall'Antonia L, Davoren GK (2009) Central-place foraging in an arctic seabird provides evidence for Storer-Ashmole's halo. Auk 126:613-625

* Elliott ML, Bradley RW, Robinette DP, Jahncke J (2015) Changes in forage fish community indicated by the diet of the Brandt's cormorant (Phalacrocorax penicillatus) in the central California Current. J Mar Syst 146:50-58

Fridolfsson AK, Ellegren H (1999) A simple and universal method for molecular sexing of non-ratite birds. J Avian Biol 30:116-121

Fritz H, Said S, Weimerskirch H (2003) Scale-dependent hierarchical adjustments of movement patterns in a longrange foraging seabird. Proc R Soc B 270:1143-1148

* Hallworth MT, Marra PP (2015) Miniaturized GPS tags identify non-breeding territories of a small breeding migratory songbird. Sci Rep 5:11069

*Harcourt RG, Bradshaw CJA, Dickson K, Davis LS (2002) Foraging ecology of a generalist predator, the female New Zealand fur seal. Mar Ecol Prog Ser 227:11-24

*Hays GC, Ferreira LC, Sequeira AMM, Meekan MG and others (2016) Key questions in marine megafauna movement ecology. Trends Ecol Evol 31:463-475

*Hyrenbach KD, Veit RR (2003) Ocean warming and seabird communities of the southern California Current System 
(1987-98): response at multiple temporal scales. Deep Sea Res II 50:2537-2565

Ito M, Minami H, Tanaka Y, Watanuki Y (2009) Seasonal and inter-annual oceanographic changes induce diet switching in a piscivorous seabird. Mar Ecol Prog Ser 393: 273-284

Ito M, Takahashi A, Kokubun N, Kitaysky AS, Watanuki Y (2010) Foraging behavior of incubating and chick-rearing thick-billed murres Uria lomvia. Aquat Biol 8:279-287

Kato A, Watanuki Y, Naito Y (2003) Foraging behaviour of chick-rearing rhinoceros auklets Cerorhinca monocerata at Teuri Island, Japan, determined by acceleration-depth recording micro data loggers. J Avian Biol 34:282-287

Keller CA, Garrison L, Baumstark R, Ward-Geiger LI, Hines E (2012) Application of a habitat model to define calving habitat of the North Atlantic right whale in the southeastern United States. Endang Species Res 18:73-87

Kuroki M, Kato A, Watanuki Y, Niizuma Y, Takahashi A, Naito Y (2003) Diving behavior of an epipelagically feeding alcid, the rhinoceros auklet (Cerorhinca monocerata). Can J Zool 81:1249-1256

*LLouzao M, Pinaud D, Péron C, Delord K, Wiegand T, Weimerskirch H (2011) Conserving pelagic habitats: seascape modelling of an oceanic top predator. J Appl Ecol 48:121-132

Matich P, Heithaus MR, Layman CA (2011) Contrasting patterns of individual specialization and trophic coupling in two marine apex predators. J Anim Ecol 80:294-305

*Maxwell SM, Conners MG, Sisson NB, Dawson TM (2016) Potential benefits and shortcomings of Marine Protected Areas for small seabirds revealed using miniature tags. Front Mar Sci 3:1-11

* McGowan J, Hines E, Elliott M, Howar J, Dransfield A, Nur N, Jahncke J (2013) Using seabird habitat modeling to inform marine spatial planning in central California's National Marine Sanctuaries. PLOS ONE 8:e71406

* Melvin EF, Parrish JK, Conquest LL (1999) Novel tools to reduce seabird bycatch in coastal gillnet fisheries. Conserv Biol 13:1386-1397

*Miller AK, Sydeman WJ (2004) Rockfish response to lowfrequency ocean climate change as revealed by the diet of a marine bird over multiple time scales. Mar Ecol Prog Ser 281:207-216

Nel DC, Lutjeharms JRE, Pakhomov EA, Ansorge IJ, Ryan PG, Klages NTW (2001) Exploitation of mesoscale oceanographic features by grey-headed albatross Thalassarche chrysostoma in the southern Indian Ocean. Mar Ecol Prog Ser 217:15-26

Panigada S, Zanardelli M, MacKenzie M, Donovan C, Mélin F, Hammond PS (2008) Modelling habitat preferences for fin whales and striped dolphins in the Pelagos Sanctuary (Western Mediterranean Sea) with physiographic and remote sensing variables. Remote Sens Environ 112: 3400-3412

* Phalan B, Phillips RA, Silk JRD, Afanasyev V and others (2007) Foraging behaviour of four albatross species by night and day. Mar Ecol Prog Ser 340:271-286

R Core Team (2016) R: a language and environment for statistical computing. R Foundation for Statistical Computing, Vienna. www.r-project.org

Raymond B, Lea MA, Patterson T, Andrews-Goff V and others (2015) Important marine habitat off east Antarctica revealed by two decades of multi-species predator tracking. Ecography 38:121-129

Redfern JV, Ferguson MC, Becker EA, Hyrenbach KD and others (2006) Techniques for cetacean-habitat modeling. Mar Ecol Prog Ser 310:271-295

Robinson CJ (2004) Responses of the northern anchovy to the dynamics of the pelagic environment: identification of fish behaviours that may leave the population under risk of overexploitation. J Fish Biol 64:1072-1087

* Rodríguez A, Negro JJ, Mulero M, Rodríguez C, Hernández-Pliego J, Bustamante J (2012) The eye in the sky: combined use of unmanned aerial systems and GPS data loggers for ecological research and conservation of small birds. PLOS ONE 7:e50336

* Rodríguez JP, Fernández-Gracia J, Thums M, Hindell MA and others (2017) Big data analyses reveal patterns and drivers of the movements of southern elephant seals. Sci Rep 7:112

Santora JA, Field JC, Schroeder ID, Sakuma KM, Wells BK, Sydeman WJ (2012) Spatial ecology of krill, micronekton and top predators in the central California Current: implications for defining ecologically important areas. Prog Oceanogr 106:154-174

* Santora JA, Schroeder ID, Field JC, Wells BK, Sydeman WJ (2014) Spatio-temporal dynamics of ocean conditions and forage taxa reveal regional structuring of seabirdprey relationships. Ecol Appl 24:1730-1747

Shaffer SA, Weimerskirch H, Scott D, Pinaud D and others (2009) Spatiotemporal habitat use by breeding sooty shearwaters Puffinus griseus. Mar Ecol Prog Ser 391: 209-220

Shaver DJ, Hart KM, Fujisaki I, Bucklin D and others (2017) Inter-nesting movements and habitat-use of adult female Kemp's ridley turtles in the Gulf of Mexico. PLOS ONE 12:e0174248

Shoji A, Aris-Brosou S, Owen E, Bolton M and others (2016) Foraging flexibility and search patterns are unlinked during breeding in a free-ranging seabird. Mar Biol 163:72

* Studwell AJ, Hines E, Elliott ML, Howar J, Holzman B, Nur N, Jahncke J (2017) Modeling pelagic seabird foraging distributions to inform ocean zoning in central California. PLOS ONE 12:e0169517

* Suryan RM, Irons DB, Brown ED, Jodice PGR, Roby DD (2006) Site-specific effects on productivity of an upper trophic-level marine predator: bottom-up, top-down, and mismatch effects on reproduction in a colonial seabird. Prog Oceanogr 68:303-328

* Takahashi A, Kuroki M, Niizuma Y, Watanuki Y (1999) Parental food provisioning is unrelated to manipulated offspring food demand in a nocturnal single-provisioning alcid, the rhinoceros auklet. J Avian Biol 30:486-490

Takahashi A, Ito M, Suzuki Y, Watanuki Y and others (2015) Migratory movements of rhinoceros auklets in the northwestern Pacific: connecting seasonal productivities. Mar Ecol Prog Ser 525:229-243

* Thaxter CB, Lascelles B, Sugar K, Cook AS and others (2012) Seabird foraging ranges as a preliminary tool for identifying candidate Marine Protected Areas. Biol Conserv 156:53-61

* Thayer JA, Sydeman WJ (2007) Spatio-temporal variability in prey harvest and reproductive ecology of a piscivorous seabird, Cerorhinca monocerata, in an upwelling system. Mar Ecol Prog Ser 329:253-265

* Torres LG, Thompson DR, Bearhop S, Votier S, Taylor GA, Sagar PM, Robertson BC (2011) White-capped albatrosses alter fine-scale foraging behavior patterns when associated with fishing vessels. Mar Ecol Prog Ser 428:289-301

Vilchis LI, Ballance LT, Fiedler PC (2006) Pelagic habitat of 
seabirds in the eastern tropical Pacific: effects of foraging ecology on habitat selection. Mar Ecol Prog Ser 315: 279-292

Wakefield ED, Phillips RA, Matthiopoulos J (2009) Quantifying habitat use and preferences of pelagic seabirds using individual movement data: a review. Mar Ecol Prog Ser 391:165-182

Waugh SM, Troup C, Filippi D, Weimerskirch H (2002) Foraging zones of southern royal albatrosses. Condor 104: 662-667

Weimerskirch H (2007) Are seabirds foraging for unpredictable resources? Deep Sea Res II 54:211-223

Weimerskirch H, Cherel Y, Cuenot-Chaillet F, Ridoux V (1997) Alternative foraging strategies and resource al-

Editorial responsibility: Rory Wilson,

Swansea, UK location by male and female wandering albatrosses. Ecology 78:2051-2063

*Wells BK, Santora JA, Henderson MJ, Warzybok P and others (2017) Environmental conditions and prey-switching by a seabird predator impact juvenile salmon survival. J Mar Syst 174:54-63

* Yamamoto T, Watanuki Y, Hazen EL, Nishizawa B, Sasaki H, Takahashi A (2015) Statistical integration of tracking and vessel survey data to incorporate life history differences in habitat models. Ecol Appl 25:2394-2406

Young HS, Maxwell SM, Conners MG, Shaffer SA (2015) Pelagic marine protected areas protect foraging habitat for multiple breeding seabirds in the central Pacific. Biol Conserv 181:226-235

Submitted: July 13, 2017; Accepted: January 24, 2018

Proofs received from author(s): March 1, 2018 